ELORE (ISSN 1456-3010), vol. $13-2 / 2006$.

Julkaisija: Suomen Kansantietouden Tutkijain Seura ry.

[http://cc.joensuu.fi/ /oristi/2_06/leh2_06.pdf]

\title{
KOLUMNI:
}

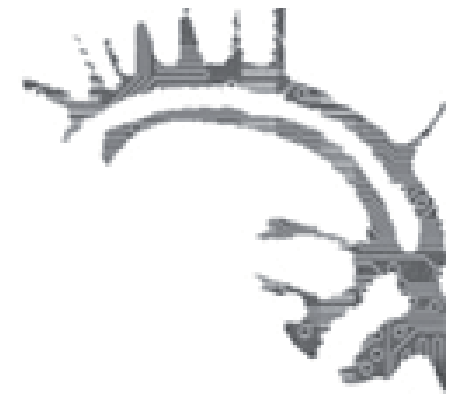

\section{FOLKLORESTA JA FOLKLORISTIIKASTA. VOIKO TIETEEN KEHITYSTÄ ENNUSTAA?}

\author{
Outi Lehtipuro
}

Voiko tieteen kehitystä ennustaa? Kysymys herää, kun luen kolmenkymmenen vuoden takaisia folk:loren ja folkloristiikean määritelmiäni (Spectrum 3, 1977). Tavoitteeni oli kuvata voimakasta murrosta elävän ja moneen suuntaan kurkottavan tieteenalan lausumaton konsensus, mutta myös sen sisäänrakennettu potentiaali. Sen juuret olivat "suomalaisen" tutkimusmenetelmän tiedonintressissä, tieteellisessä mielikuvituksessa ja tutkimuksen käytännöissä. Nykyaikaisesti omimmillaan folkloristiikka tuntui olevan elävän suullisen perinteen kenttätutkimuksena. Tämä oli vastaus ilmassa olevaan antropologian haasteeseen ja reaktio arkistoaineistojen "kontekstittomuuden" aiheuttamaan turhautumiseen.

Hakusanoista Folkloristiikkea luonnehti tutkimusalaa tiiviin yleistävästi, laajempi Folklore perustui ennen muuta ajankohtaiseen suomalaiseen tutkimustilanteeseen. Teksti tasapainoilee menneen ja tulevan välillä sisäisesti ristiriitaisellakin tavalla. Monet asiat ilmaisisin tänään toisin. En käyttäisi folklorea ja perinnettä synonyymeinä enkä puhuisi perinteen muistamisesta: kuten kirjailija Hannu Raittila asian (TV1 5.10.2006) ilmaisi, muistaminen on myös sepittämistä.

Artikkelissa on kolme kuvaa: valokuva lasten pihaleikistä edusti uutta "helsinkiläistä" tutkimuskohdetta, ja Juha Pentikäisen kaavio perinneviestin dimensioista "turkulaista" näkemystä folkloristin tutkimuskohteesta. Kolmannessa kuvassa haudalle asetettu Uher-kenttänauhuri tallentaa karjalaista itkijää. Kuvaa voisi tulkita pitempäänkin; sen olennainen sanoma oli, että "perinteen keruun mullistanut" kevyt nauhuri tekee tieteellisesti mahdolliseksi aivan uusia asioita. Videokamerasta ei vielä tiedetty mitään.

\section{MiteN SITTEN KÄVI?}

Toteutuneen kehityksen perspektiivistä tilannekuvauksessani on kuin arvoituksessa sekä harhaan johtavaa että perille vievää ainesta. Se, mitä kirjoitin mahdollisuudesta 


\section{FOLKLORESTA JA FOLKLORISTIIKASTA}

tieteellisesti suunniteltujen kenttätyöretkien avulla saada monipuolista ja syvällistä tietoa folkloresta ja sen merkityksistä, oli toteutumaton optio: vasta muutamat opinnäytteet olivat alkaneet avata näköaloja elävään kertomusperinteeseen.

Suuren alkuinnostuksen ja muutaman hienon tutkimuksen jälkeen kenttätutkimus näyttää menettäneen kiinnostavuuttaan "kirjoittavan kertojan" hyväksi. Kilpakeruuaineistojen suosio on merkinnyt luopumista siitä folkloristiikan potentiaalista, joka sisältyy ajatukseen suullisen luonnollisesta ensisijaisuudesta kirjoitettuun verrattuna. Toisaalta pelko arkistoaineistojen kuolemasta on osoittautunut turhaksi: kehittämällä teoriaa ja oppimalla kysymään toisin vanhatkin aineistot on saatu elämään.

Odottamaani vähemmän kiinnostusta on ollut folkloristiikan ja kansatieteen, henkisen ja aineellisen, lähentämiseksi toisiinsa. Kulttuurin materiaalinen, esineellinen ja tekninen puoli on pysynyt etnologian reviirillä. Fyysisen ympäristön kokemuksesta folkloren kuvat kuitenkin syntyvät ja käytännöllisiinkin ratkaisuihin sisältyy arvovalintoja ja sellaista mielekkyyttä, joka ei selity aineellisen maailman ominaisuuksista. Elämismaailman ymmärtäminen jää vajaaksi.

Oikeaan osuneitakin ennustuksia on. Hahmottamani kuva folkloresta paikallisena ja globaalina, yksilöllisenä ja yhteisöllisenä asiana, "toisena kielenä", on saanut konkreettisia toteutuksia. Myös kansanrunoudentutkimuksen syntyyn johtanut havainto, kulttuuristen mielikuvien ja konstruktioiden hämmästyttävä sitkeys ja pysyvyys, on vertailevan tutkimuksen teoreettisen uudistumisen myötä saanut yhä uusia tulkintoja. Hauska on myös todeta, miten rautalangasta väännetty 1970-luvun periaatepuhe perinteen lajeista on niiden modaalisen ja emic-olemuksen täsmentyessä saanut todellista sisältöä.

Ajatellessani (vielä hieman sumeasti) yhteisöllisyyttä folkloren ominaisuutena, eikä vain sen synnyn ja säilymisen ehtona, olin kaukonäköisempi kuin tiesin. Juuri tässä voisi olla yksi kiintopiste, jos ja kun folkloristiikka haluaa määritellä itsensä teoreettisesti omaleimaisena tieteenä, "joka kykenee valaisemaan ihmisen ajattelua ja toimintaa ohjaavia perustavanlaatuisia sosiaalisia, kulttuurisia ja kielellisiä prosesseja" (Briggs 1988, 5, käännös O. L.).

\section{ONGELMA JA RATKAISU}

1970-luvun keskeinen ongelma mielestäni oli, millaisena aineistona yhteisiä kertomuksia ja muuta suullista perinnettä pitäisi tulkita. Mistä ne nimenomaan folklorena kertovat? Kysymys oli aidosti avoin, ja sen ratkaisut ovat olleet täynnä yllätyksiä. Palapelin paloja oli olemassa, mutta monet niistä olivat väärin päin ja kuva pahasti kesken. Kirjoittaessani tarinoiden historiallisesta totuusarvosta totesin niiden ilmaisevan eniten "kertojistaan ja heidän maailmankuvastaan ja asenteistaan". Silloin en tiennyt, mitä tämä voisi pitää sisällään. Nyt tiedän.

Ehkä suurin folkloristisen itseymmärryksen tilapäinen vinksahdus oli kirjoittaa, että "suppeimmillaan folklore voidaan käsittää [.] kansan sanataiteeksi”. Nyt näyttää selvältä, että asia on nimenomaan päinvastoin: koko folkloren olemassaolon perusta on ihmisten universaali esteettinen kapasiteetti. Folklore puhuu tärkeistä 


\section{OUTI LeHTIPURO}

asioista, ja tärkeitä asioita on kaikissa yhteiskunnissa ilmaistu esteettisin keinoin. Laajemmassa filosofisessa mielessä on luonnollista, että se, mitä folkloristi tutkii, yhdistää usein estetiikan ja etiikan: hyvä, kaunis ja tosi kuuluvat yhteen.

Olisiko kehitykselle ollut vaihtoehtoja? Folkloristiikan metaforinen partneri oli alun perin (historiallinen) kielentutkimus, mutta juuri tämä yhteys oli 1970-luvulla ohut. On kiehtovaa ajatella, mitä folkloren ymmärryksellemme olisi tapahtunut, jos kumppanuus lingvistiikan kanssa olisi jatkunut strukturalismia pidemmälle. Mitä jos Virittäjä edelleen olisi ollut kielen ja kulttuurin yhteinen aikakauskirja ja sen vuonna 1983 julkaisema laaja arvostelu George Lakoffin ja Mark Johnsonin teoksesta Metaphors we live by (1980) olisi kanavoitunut syvällisesti ja monipuolisesti folkloristiseen keskusteluun? Ei tunnu sattumalta, että innostuneen ja pohdiskelevan esittelyn kirjoittaja, kognitiivisen kielentutkimuksen Suomeen juurruttanut Pentti Leino, on taustaltaan 1960-lukulainen folkloristi. Tavassa, jolla hän kirjaa lukee, näkyy nuoruudenkokemuksen varjo.

\section{KirJallisuUs}

BRIGGS, CHARLES L. 1988: Competence in Performance: The Creativity of Tradition in Mexicano Verbal Art. Philadelphia: University of Pennsylvania Press.

LEINO, PENTTI 1983: Mielikuvat kielikuvien takana. [Arvostelu teoksesta Lakoff, George \& Johnson, Mark 1980: Metaphors We Live by.] - Virittäjä 87: 107-116 SPECTRUM 3, 1977: [Hakusanat Folklore ja Folkloristiikka.] Porvoo: WSOY.

FL Outi Lehtipuro on folkloristiikan tutkija Jonsuun yliopistossa. 